囊胞状リンパ管腫の診断と治療

\author{
丹羽 秀夫・木田 亮紀・遠藤 壮平 \\ 山田洋一郎・酒井 文隆・根本 則道*
}

\title{
Diagnosis and Treatment of Cystic Lymphangioma
}

\author{
Hideo Niwa, Akinori Kida, Sohei Endo, Yoichiro Yamada, \\ Fumitaka Sakai and Norimichi Nemoto \\ (Nihon University School of Medicine)
}

\begin{abstract}
Cystic lymphangiomas occur as the result of a congenital malformation of the lymphatic system and are histologically benign tumors, with spaces lined by true endothelium. We reviewed our 10years of experience in treating cystic lymphangioma of the head and neck. Magnetic resonance imaging (MRI) was used to assess the size and extent of the lesion and to assist in planning the surgical approach. We performed surgical resection on all patients. A brief discussion of cystic lymphangioma and its management is presented, followed by a review of 8 patients with cystic lymphangioma of the head and neck treated at the Department of Otorhinolaryngology, Nihon University.
\end{abstract}

Key words : cystic lymphangioma, MRI, treatment

はじめに

リンパ管腫はリンパ管の先天的な形成異常とされ，組 織学的にリンパ管内皮細胞で内側を覆われた霊胞状の管 腔でできた良性の腫瘍性病変である11.リンパ管腫は頭 頸部領域に発生する頻度が高く, 診断は比較的容易であ る. 今回我々は, 日本大学医学部耳鼻咽喉科学教室で経 験した震胞状リンパ管腫 8 例について若干の文献的考察 を加えてその診断と治療を検討した。

\section{対象症例}

症例は1984年 6 月から1993年 8 月までの間に日本大学 医学部耳鼻咽喉科で治療された䨢胞状リンパ管腫は 8 例 であった.すべての症例とも外科的治療を受け, 病理組 織学的に, 囊胞状リンパ管腫と診断されたものを対象と
した．表 1 飞性別，年齢，部位，主訴，治療，病悩期間， 再発を示した. 症例 8 例の性別は男性 4 例, 女性 4 例で 性差なく, 初診時年路は, 2 歳から68歳(平均 37.0 歳)で あった.リンパ管腫の発生部位は左後頸部 1 例, 左前頸 部 1 例, 左頸部 2 例, 右耳下腺部 2 例, 右買下部 1 例, 右頓部 1 例であった。顎下部の症例と右耳下腺部の症例 は口腔内に腫瘍が進展していた(症例 2, 7 )。左前頸部 の症例は初診時, 触診上, 甲状腺にほぼ一致しており術 前診断では甲状腺腫瘍の診断を受けていた。手術時に腫 瘍は甲状腺下の気管輪 $1 \sim 3$ の高さにあり, 気管壁に接 していたが甲状腺との癒着はなかった(症例 3 ). 症状に ついてみると咽喉頭異常感を主訴に来院した 1 例以外の 症例は全て，頭頸部領域における腫脹を主訴に来院した。 感染による急激な腫瘍の腫大のため, 疼痛を訴えた症例 
表 1 辣胞状リンパ管腫症例

\begin{tabular}{|c|c|c|c|c|c|c|c|}
\hline 症例 & 性別 & 年齢 & 部 位 & 主 訴 & 治 療 & 病悩期間 & 再発 \\
\hline 1 & 男 & 28 & 左後頸部 & 左頸部腫脹 & $\begin{array}{c}\text { 切除 } \\
1992.4 .17\end{array}$ & 約 24年 & 無 \\
\hline 2 & 女 & 2 & 右頱下部 & 右顎下部腫脹 & $\begin{array}{c}\text { 切除 } \\
1988.9 .16 \\
\text { BLM } 5.5 \mathrm{mg}\end{array}$ & 約 1 年 & 無 \\
\hline 3 & 女 & 58 & 左前頸部 & 咽喉頭異常感 & $\begin{array}{c}\text { 切除 } \\
1984.10 .29\end{array}$ & 約 2 力月 & 無 \\
\hline 4 & 女 & 57 & 左頸部 & 左頸部腫脹 & $\begin{array}{c}\text { 切除 } \\
1991.8 .6\end{array}$ & 約 3 力月 & 無 \\
\hline 5 & 男 & 26 & 右頓部 & 右煩部腫脹 & $\begin{array}{c}\text { 切除 } \\
1985.12 .13\end{array}$ & 約 20 年 & 無 \\
\hline 6 & 男 & 18 & 右耳下腺部 & 右耳下腺部腫脹 & $\begin{array}{c}\text { 切除 } \\
1993.10 .22\end{array}$ & 約 4 年 & 無 \\
\hline 7 & 女 & 39 & 右耳下腺部 & 右耳下腺部腫脹 & $\begin{array}{c}\text { 切除 } \\
1988.6 .14\end{array}$ & 約 3 力月 & 無 \\
\hline 8 & 男 & 68 & 左頸部 & 左頸部腫脹 & $\begin{array}{c}\text { 切除 } \\
1985.6 .21\end{array}$ & 約 2 力月 & 無 \\
\hline
\end{tabular}

BLM : bleomycin

（症例 5 ) 以外は腫脹した部位での疼痛の訴えはなかった。 腫瘍が急激に増大した症例が 3 例であった. (症例 4，5， 6 ). ミルクの誤燕により近医受診し，口腔内に腫瘍を 指摘された症例を認めた (症例 2 ). 咽喉頭異常感のみで 受診し,診察時に前頸部に弾性軟の腫瘍を指摘された(症 例 3 ). 交通事故による腫瘍部位の外傷後, 徐々に腫脹 し, 圧迫感を訴える症例も認めた (症例 1 ). 腫瘍の圧迫 による呼吸困難の症状を呈する症例は我々の症例では認 めなかった．治療は当科で全ての症例に外科的切除が行 なわれた．初診時から手術までの平均期間は約 1.5 力月 であった(期間：約 1 カ月〜 4.5 力月). 手術のみの症例 が 7 例(症例 $1,3 \sim 8$ ), 手術の他にブレオマイシンの 局注を施行した症例が 1 例(症例 2 )であった。 この症例 2 は顎下部の腫瘍は切除したが，口腔底粘膜と顎下横隔 膜の間にある腫瘍の切除を行なうと舌神経損傷などの合 併症の可能性が高いため, ブレオマイシンを局注した. ブレオマイシンはいずれも手術時と手術後に腫瘍部位に 注入された.ブレオマイシンの総投与量は $5.5 \mathrm{mg}$ (症 例 2 )であった。ブレオマイシンによる肺瀻維症, 発熱 などの副作用は認めなかった，手術後の合併症としては 末梢性顔面神経麻痺(特に下買縁枝) (症例 2,6) と血腫 （症例 5 ）が認められた. 顔面神経麻痺は全て一過性の麻 痺で術後しばらくして軽快した，血腫も術後すぐに消退 した．次に代表的な 1 症例を呈示する。

\section{症 例 6}

症例 : 18歳, 男性.

初診日：1993年 8 月 26 日.

主訴 : 右耳下腺部腫脹.

既往歷・家族歷 : 特記すべきことなし

現病歷：1993年 5 月頃より学校の教師に顔面の腫脹を 指摘され近医受診し，当科を紹介され精查治療のため受 診した. 初診時右耳下腺部から頓部にかけて約 $6.5 \times 8.5$ $\mathrm{cm}$ の弾性軟の境界は比較的明瞭な, 圧痛のない腫瘍を 認めた。単純 CT 所見では筋層と同程度の腫瘍陰影を認 めた．造影 CT では腫瘍の造影効果は認められなかった （図 1 ）.MRI 所見は $\mathrm{T} 1$ 強調画像で腫瘍は筋層よりや や強い信号を呈し，T1 強調画像の造影剤 (Gd-DTPA) 投与後では腫瘍の信号に変化は見られなかった．T2 強 調画像では高信号を呈した(図 2 )。術前, 穿刺吸引細胞 診を施行したが，内容物は透明であり，赤血球も見られ たがリンパ球優位であり，一部上皮細胞が見られた。画 像所見, 細胞学的所見から虽胞状リンパ管腫を考克, 1993年10月22日手術を行なった。

手術所見：S 字状切開を施し，皮膚を剝離，反転した。 茎状突起と乳様突起の間から出た顔面神経本幹を確認し 各分枝を筋層に入る部分まで露出し確認した。リンパ管 腫は多房性で耳下腺の頭側 $1 / 3$ から側頭上窩の皮下に， 筋突起から煩骨の高さで存在し, 耳下腺浅葉を含めて腫 瘍を摘出した．腫瘍の $90 \%$ は摘出したが一部残した．病 


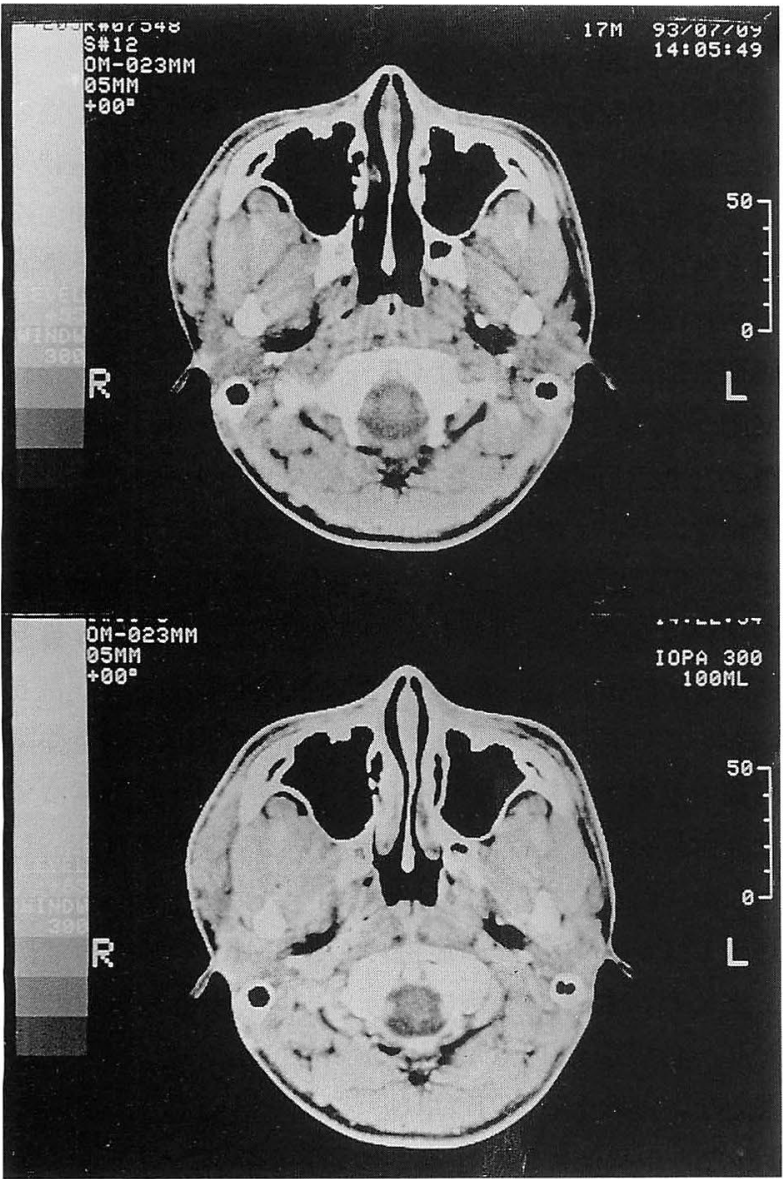

図1 症例の CT 所見(上：単純, 下：造影)

理組織学的検査では一層の内皮細胞に覆われ，様々に拡 張した霊胞性の部分を認めた(図 3 )。リンパ管の内腔に は淡紅色の無構造物が見られた。術後, 下額縁枝の一過 性の麻痺を生じたが，しばらくして回復した。経過良好 で現在まで再発を認めない。

\section{考察}

リンパ管腫は先天性の腫瘍と考兄られているが，リン パ系の発達が完全には理解されて招らずリンパ管腫の発 生に関しては不明のままである21，本症の成因について は種々の説があり, リンパ系は 5 つの原始囊から発生し， これら原始囊の内皮細胞の組織芽が末梢リンパ系を形成 するために遠心性に拡がる説，胎生期に原始囊の部分か ら派生したリンパ組織の一部から発生する説, 隔離され たリンパ組織は囊胞を形成し，虽胞の壁由来の内皮細胞 の繊維膜組織芽が周囲の正常組織に侵入し，纎維組織か

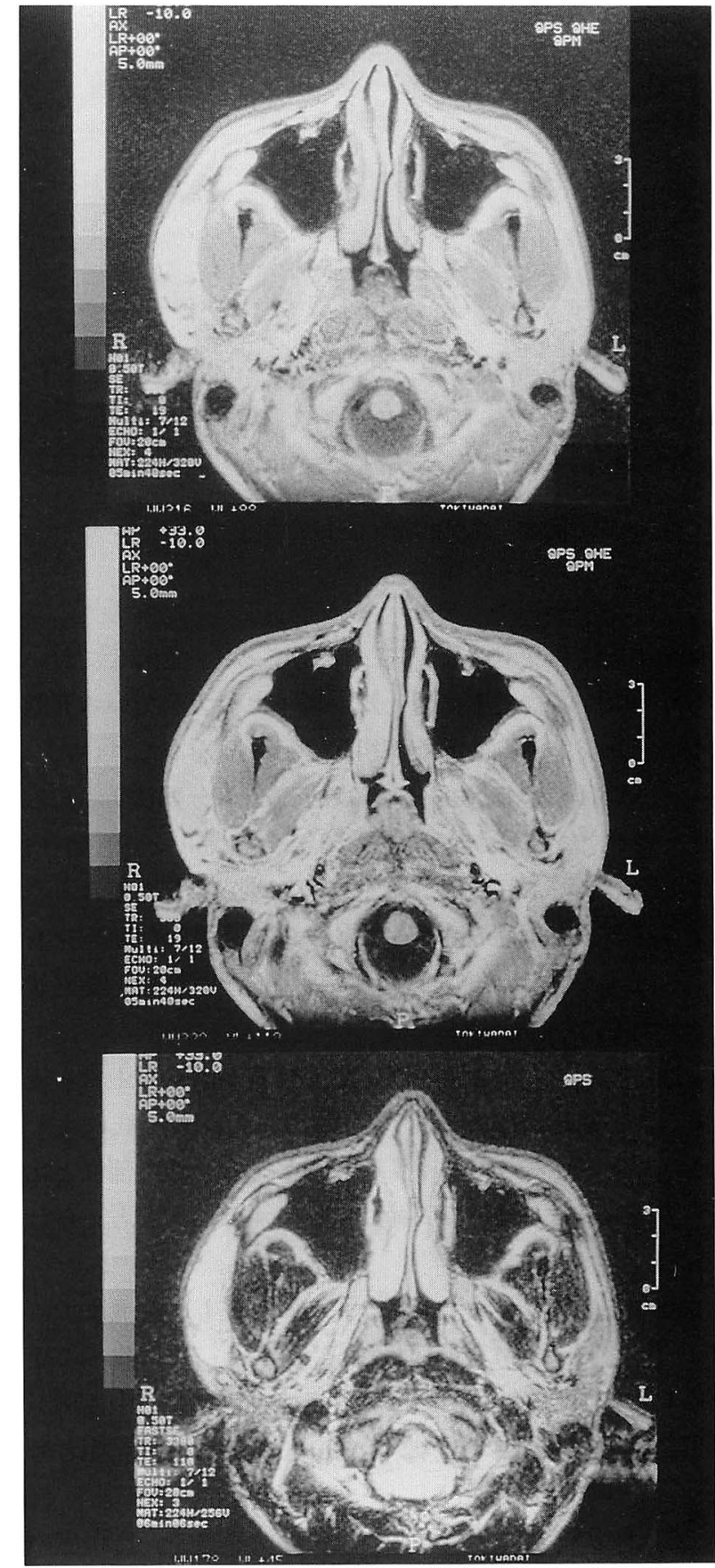

図 2 症例の MRI 所見(上: T1 強調画像, 中 : T1Gd-DTPA 下 : T2 強調画像)

らの分泌液で満たした囊胞を形成するように導く説など が挙げられている3゙.

組織学的には一層の平らな内皮細胞で覆われ，様々な 厚さの間質は結合組織よりなり, リンパ組織, 筇組織, 


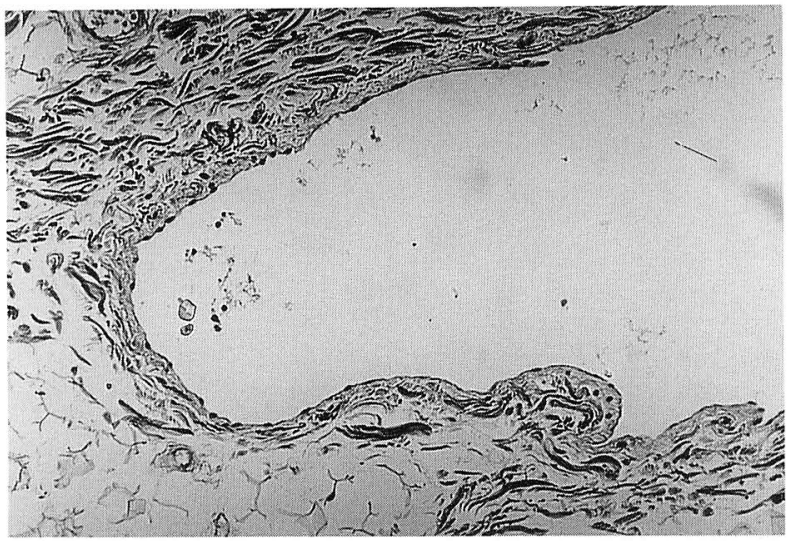

図 3 病理組織所見 $(\mathrm{HE}$ 染色 $\times 100)$

血栓や被膜片を含んでいることもある1). 症例 6 に扮い ても一層の内皮細胞に覆われ，様々に拡大している囊胞 性の部分があり特徵的な病組織学的所見を有していた。

リンパ管腫の組織学的分類にAschoff の分類法4) が知ら れ，次の様に分類されている１１．単純性リンパ管腫(内 皮細胞で被覆された薄い壁を有するリンパ管の集合より なる.) 2 . 海綿状リンパ管腫(著しく拡張した管腔を有 する.) 3 . 囊胞状リンパ管腫(リンパ管の管腔が囊胞状 を呈する.）

発生部位としては頭頸部が最も頻度が高く, 中でも後 頸三角部に出現しやすい225). 顔面, 舌, 口腔底にもし ばしば見られる。これはリンパ系が全身の他の部位と比 べて頭頸部では複雑で広範囲に存在するからと考兄られ る.

$50 \sim 60 \%$ の症例が生下時にすでに存在し，2歳までに 80 90\%と汪とんどの症例で発症している1). 我々の症 例は受診時は高年齢であるが，発症年齢は 8 例中 4 例が 明確な発症年齢は不詳だが，恐らく乳幼児での発症と考 えられる。

臨床症状としては発生した部位の大きさや，合併症の 有無によって異なるが，一般に無痛性で境界不明膫であ り，波動性のある弾性軟な腫瘍を呈する、リンパ管腫が 舌, 口腔底, 咽頭, 喉頭扣よび縱隔へ進展する様な症例 は呼吸困難，燕下困難をきたしてくる2)6)。我々の症例 においても症例 3 で腫瘍が気管壁に接していたが，呼吸 困難を訴觉るようなことはなかった，外傷や感染などの 刺激の結果，腫瘍の急激な腫大をきたしたり，炎症，圧 痛, 囊胞内出血を認めることがある25). 症例 1 は交通
事故により腫瘍部位の外傷の既往があり，外傷後，腫大 してきたと思われる。

診断は比較的容易であり, 触診上, 可動性で波動性の ある腫瘍を示すものもあり, 粘膜下に存在する囊胞状り ンパ管腫の場合, 明るい光線で透過性を示すのも他の疾 患と鑑別する上で有用である．内溶液の細胞診では霬胞 でめれば淡黄色で透明であり, リンパ球が存在している。 画像診断による診断では CT, MRI が有用で78)，特に MRI が優れていると言われる ${ }^{8)}$. 多くのリンパ管腫が特 徵的な MRI 画像を呈していると考光られ8) 10)，T1 強 調画像に执いては筋肉より低信号, 又は同程度の信号を 示し， T2 強調画像に招いては脂肪より高信号を示寸と 多くの文献等で述べられている8) 10)。このことは襄胞 に液体が貯留していることを強く反映している，症例 6 に招いては耳下腺のリンパ管腫の MRI 画像は T1 強調 画像で筋層より同程度〜高信号を呈し，T2 強調画像で は高信号を示した。T1Gd 造影所見で造影効果は認めら れなかったが，このことは囊胞内への血流がないことを 意味している，我々の症例の CT, MRI 画像を表 2 に まとめた，我々の症例は T1，T2でも高信号を呈して 特り，必ずしも T1 で低信号が特徵的な所見であるとは 言光ないと考兄る.CT (単純, 造影), MRI (T1，TIGd, T2）などの画像に拈いて囊胞性病変が確認でさるが，こ れが聖胞状リンパ管腫であるということを特定すること は難しい，診断は視診, 触診, 細胞診, 画像所見などに より，囊胞状リンパ管腫と診断できる.

リン八管腫の治療は従来より, 外科的療法, 放射線療 法，硬化剂の注入療法などがある，我々の症例は全ての 症例で外科的治療(腫瘍全摘, 亜全摘を含め)が行なわれ た．放射線療法は効果が不十分であり，局所の発育を阻 害することや悪性腫瘍を誘発するなどの副作用のため原 則として行なわれるべきではないが，咽喉頭のリンパ管 腫で他の治療が行ないえない場合に，行なわれることが

表 2 賈胞状リンパ管腫の CT, MRI 所見

\begin{tabular}{lcc}
\hline \hline 画像 & 条 件 & 信号強度 \\
\hline \multirow{2}{*}{ CT } & 単 純 & 低〜等信号 \\
& 造 影 & 造影効果なし \\
\hline \multirow{3}{*}{ MRI } & T1 強調画像 & 筋層より低〜高信号 \\
& T1Gd-DTPA & 造影効果なし \\
& T2 強調画像 & 筋層より高信号
\end{tabular}


ある3). 症例 2 に抢いてはブレオマイシンの局注も行な った. 症例 2 では術中, 術後と合わせてブレオマイシン を総量 $5.5 \mathrm{mg}$ 使用し, 腫瘍は消失した. 1 例であるが

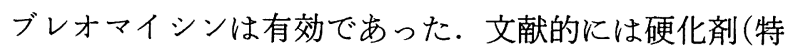
に OK-432)の注入による有効性が示唆されて扣り11) 13) 我々の症例では経験されてはいない，治療の第 1 選択は 外科的治療と考えるが外科的治療が難しく合併症を示す 可能性のある症例に対して OK-432 の使用を今後, 検討 していきたいと考㝋る。

外科的治療のみ行なった症例は，一過性の末梢性顔面 神経麻痺と血腫以外は術後の感染, 敗血症, 瘦孔形成, 神経損傷などの重篤な合併症は認められなかった．末梢 性顔面神経麻㽻と血腫も術後には消失し, 現在まで合併 症の影響は認めない.リンパ管腫の再発は一般に外科的 治療後, 1 年以内のことが多く, 腫瘍の一部を残すと 10 $\sim 15 \%$ 再発するとの報告がある ${ }^{3)}$. 我々の症例は現在ま で再発は認めない, 我々の施設では治療法の第 1 選択と して外科的に許される限り, 周囲組織を含めて十分に摘 出するのが望ましいと考える.

$$
\text { まとめ }
$$

我々は過去 10 年間, 当教室で経験した 8 例の囊胞状リ ンパ管腫について検討し若干の考察を加えた. MRI は 有用であるが，確実性はない，治療はすべて外科的治療 を行なった。

\section{参考文献}

1) Brooks J : Cystic hygroma of the neck. Laryngoscope $83: 117 \sim 128,1973$.

2 ) Kennedy TL : Cystic hygroma-lymphangioma ; a rare and still unclear entity. Laryngoscope $99: 1 \sim 10,1989$.

3 ) Emery PJ, Bailey CM and Evans JNG : Cystic hgroma of the head and neck. J Laryngol Otol $98: 613 \sim 619,1984$.

4 ) 伊藤千鶴, 橋本 温, 佐々木香, 他 : 開咬を伴った舌リン パ管腫の一例. 日口外誌 $36: 2567 \sim 2573,1990$.

5 ) Singh S, Baboo ML and Pathak IC : Cystic lymphangioma in children; report of 32 cases including lesions at rare sites. Surgery $69: 947 \sim 951,1971$.

6 ）中野美和子, 佐伯守洋, 黒田達夫, 他: 呼吸障害を伴ら頸 部リンパ管腫の治療. 小児外科 $25: 407 \sim 414,1993-4$.

7 ) Silverman ML, Korobkin M and Moore AV : CT diagnosis of cystic hygroma of the neck. J Comput Assist tomogr $7: 519 \sim 520,1983$.

8 ) Siegel MJ, Glazer HS, Amour TE, et al : Lymphangiomas in children; MR imaging. Radiology $170: 467 \sim 470,1989$.

9 ) 高橋㓐正: 全身の MRI. 334頁, 南江堂, 東京, 1993.

10) Goshen $S$ and Ophir D : Cystic hygroma of the parotid gland. J Laryngol Otol $107: 855 \sim 857,1993$.

11) Ogita $S$, Tsuto $T$, Deguchi $E$, et al : OK-432 therapy for unresectable lymphangiomas in children. J Pediatr Surg $26: 263 \sim 270,1991$.

12）荻田修平,伝 俊秋, 中村 香, 他 : リンパ管腫の OK-432 局 注療法による治療. 小児外科 $25: 371 \sim 376,1993-4$.

13）岩田光正, 岡部郁夫, 野中倫秋, 他 : リンパ管腫の OK-432 局 注療法による治療. 小児外科 $25: 377 \sim 383,1993-4$.

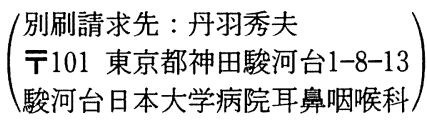

